\title{
CONCENTRATIONS AND FLUXES OF DISSOLVED NUTRIENTS IN THE YANGTZE RIVER: LONG-TERM TRENDS AND ECOLOGICAL IMPACTS
}

\author{
Yandan FU, Jiahui KANG, Ziyue LI, Xuejun LIU, Wen XU ( $\triangle$ )
}

College of Resources and Environmental Sciences, National Academy of Agriculture Green Development, Key Laboratory of Plant-Soil Interactions of the Ministry of the Environment, China Agricultural University, Beijing 100193, China.

\section{KEYWORDS}

atmospheric deposition, ecological impacts, nitrogen sources, nutrients, Yangtze River Delta

\section{HIGHLIGHTS}

- Historic trends in nutrient loading and flux in the Yangtze River were analyzed.

- Decreasing trends in the concentrations and fluxes of DSi were found.

- Significant increasing trends in DIN and DIP concentrations were observed.

- The frequency and area covered by red tide outbreaks substantially increased.

- Atmospheric deposition become a vital factor influencing DIN loadings and fluxes.

Received December 30, 2019;

Accepted May 12, 2020.

Correspondence: wenxu@cau.edu.cn

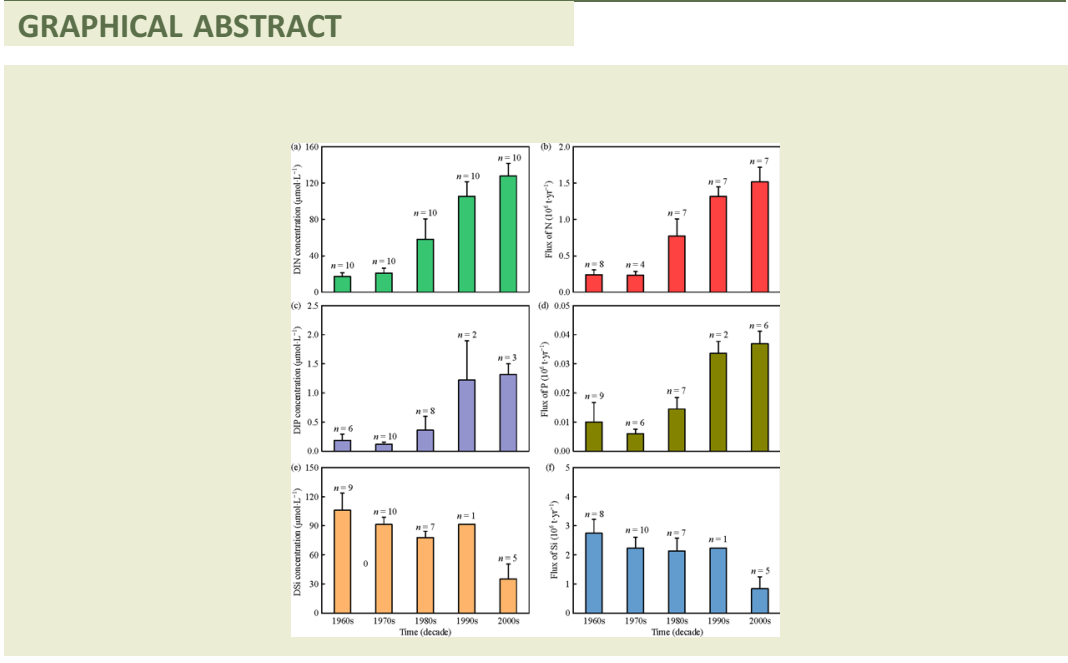

ABSTRACT

Intensifying human activity in the Yangtze River Basin (YRB) has substantially increased nutrient concentrations in the Yangtze River Estuary, leading to degradation of the coastal environment. Analysis of nutrient determinations published over the past 50 years reveals a gradual decreasing trend in the concentrations and fluxes of dissolved silicate (DSi). However, both dissolved inorganic nitrogen (DIN) and dissolved inorganic phosphate (DIP) concentrations have increased significantly since the 1970s. The frequency and area covered by red tide outbreaks have increased greatly during this period, mainly due to changes in nutrient supply ratios [i.e., N/P (DIN/DIP), N/Si (DIN/DSi), P/Si (DIP/ DSi)]. A strong correlation was found between the riverine DIN fluxes and the estimated DIN inputs from the major $\mathrm{N}$ sources, particularly fertilizers and atmospheric deposition. The data provide a comprehensive assessment of nutrients in the YRB and their ecological impacts and indicate a potentially significant influence of atmospheric deposition on DIN loadings and fluxes. 


\section{INTRODUCTION}

Rivers form important connections between the terrestrial and oceanic ecosystems and about $52 \%$ of the nitrogen input to the oceans $\left(126 \mathrm{Tg} \cdot \mathrm{yr}^{-1} \mathrm{~N}\right)$ originates from rivers ${ }^{[1]}$. In recent decades the rate at which biologically available $\mathrm{N}$ and $\mathrm{P}$ enter the terrestrial ecosystems has doubled worldwide, and the amounts of riverine $\mathrm{N}$ and $\mathrm{P}$ inputs to coastal waters have increased by a factor of more than four ${ }^{[2,3]}$. The primary impacts of these changes on estuarine and coastal areas are severe eutrophication, frequent red tide outbreaks and widening of hypoxic zones ${ }^{[4,5]}$. These changes are detrimental to sea habitats undermining the vital marine ecosystem ${ }^{[6]}$. Numerous studies demonstrate that eutrophication is the main explanation for red tides ${ }^{[7,8]}$ and that red tides require an abundance of nutrients, particularly N, P and Si. At present, nearly half of the global population lives near the coast and this population is continually increasing. Production of N, P and other nutrients proximal to marine environments has therefore increased continually, facilitating eutrophication of rivers and offshore ecosystems ${ }^{[9,10]}$. This has resulted in low sea oxygen contents, red tides formed by microalgae, and important losses to the aquaculture industry ${ }^{\left[{ }^{[}\right]}$. It is therefore essential to study the impact of nutrients $(\mathrm{N}, \mathrm{P}$ and $\mathrm{Si}$ ) in rivers and coastal ecosystems. The Yangtze is the largest river in Eurasia and is ranked globally as the third in length $(6300 \mathrm{~km})$, fourth in sediment discharge $\left(0.5 \times 10^{9} \mathrm{t} \cdot \mathrm{yr}^{-1}\right)$, and fifth in freshwater discharge $\left(9.3 \times 10^{11} \mathrm{~m}^{3} \cdot \mathrm{yr}^{-1}\right)^{[11]}$. The drainage area is about 1.8 $\times 10^{6} \mathrm{~km}^{2}$, about one fifth of the land area of China ${ }^{[12]}$. The Yangtze River flows between $24^{\circ}$ and $35^{\circ} \mathrm{N}$ and $90^{\circ}-122^{\circ} \mathrm{E}$. Along its $6300 \mathrm{~km}$ course it passes the glaciers on the QinghaiTibetan plateau in Qinghai, crosses eastward across south-west, central and eastern China and flows into the East China Sea near Shanghai.

The Yangtze River Basin (YRB) is economically important and contributes almost half of Chinese gross domestic product ${ }^{[13]}$. Intensive anthropogenic disturbances in the region have led to large changes in riverine nutrient levels and fluxes to the adjacent East China Sea in recent decades ${ }^{[14,15]}$. The sources contributing to riverine DIN loads include biosolids and animal manures, atmospheric deposition, groundwater influx and agricultural fertilizers ${ }^{[16-18]}$. Atmospheric deposition is an input of particular interest because of its magnitude and the changing composition of atmospheric nutrient ${ }^{[19]}$. For example, the bulk deposition flux of atmospheric $\mathrm{N}$ nationally has increased by nearly $8 \mathrm{~kg} \cdot \mathrm{ha}^{-1} \cdot \mathrm{yr}^{-1} \mathrm{~N}$ between the $1980 \mathrm{~s}$ and the $2010 \mathrm{~s}^{[20]}$. In addition, the wet deposition flux of dissolved phosphates in precipitate has been on average $0.2 \mathrm{~kg} \cdot \mathrm{ha}^{-1} \cdot \mathrm{yr}^{-1} \mathrm{P}$ across 41 Chinese field stations ${ }^{[21]}$. These deposited nutrients have provided the necessary conditions for the rapid growth of red tides in the Yangtze River Estuary ${ }^{[1,22]}$.

Numerous studies have focused on the YRB and adjacent coastal seas and assessed riverine nutrient sources ${ }^{[17,23]}$, spatiotemporal variation in nutrient concentrations and fluxes, and subsequent nutrient impacts on the coastal ecosystem ${ }^{[2,14,24]}$. However, most of these studies have investigated a single nutrient (often N) and have been limited to data gathered before 2000. Moreover, a lack of field monitoring data on nutrients in the YRB has necessitated the use of models in published studies, including the Global NEWS-2 model ${ }^{[23,25]}$. Most studies on atmospheric deposition have investigated nitrogen ${ }^{[26]}$. In contrast, $\mathrm{P}$ has been little studied using different sampling methods and a lack of standardization of sampling techniques ${ }^{[27,28]}$. There are few monitoring data on $\mathrm{P}$ sedimentation.

The current study synthesizes and analyzes data from a range of published scientific articles to assess the decennial trends in riverine nutrient concentrations and fluxes in the Yangtze River since the 1960s. The nutrients included are dissolved silicate (DSi), dissolved inorganic nitrogen (DIN) and dissolved inorganic phosphate (DIP). The aim was to analyze the impacts of trends in nutrient fluxes and concentrations on the estuarine ecosystem and the response of the riverine DIN flux to major $\mathrm{N}$ sources.

\section{RESULTS AND DISCUSSION}

\subsection{Trends in nutrient concentrations, fluxes and composition in river water}

Annual mean concentrations and fluxes of DIN and DIP in Yangtze River water were stable during the 1960s and 1970s (Fig. 1(a-d)) but have increased sharply since then. From the 1970s to the 2000s the concentrations of DIN and DIP increased 6 and 11 times, and their fluxes increased 6.5 and 6.2 times, respectively. These trends are mainly attributable to increased agricultural activities (application of fertilizers) and urbanization (sewage discharges) in the region ${ }^{[31]}$. There has also been an increase in $\mathrm{P}$ originating from livestock manures due to an increase in animal production during the early 21 st century $^{[25]}$. In addition, the current application rate of fertilizers in the region is almost three times that during the $1980 \mathrm{~s}^{[17]}$. Conversely, the yearly mean concentration of DSi has decreased greatly from $105 \pm 18 \mu \mathrm{mol} \cdot \mathrm{L}^{-1}$ in the 1960 s to $35 \pm 15 \mu \mathrm{mol} \cdot \mathrm{L}^{-1}$ in the 2000s. This is related to a similar magnitude of decrease in mean yearly DSi flux which declined by $69 \%$ over the same time period (Fig. 1(e,f)). The increased DIN and DIP in river water 

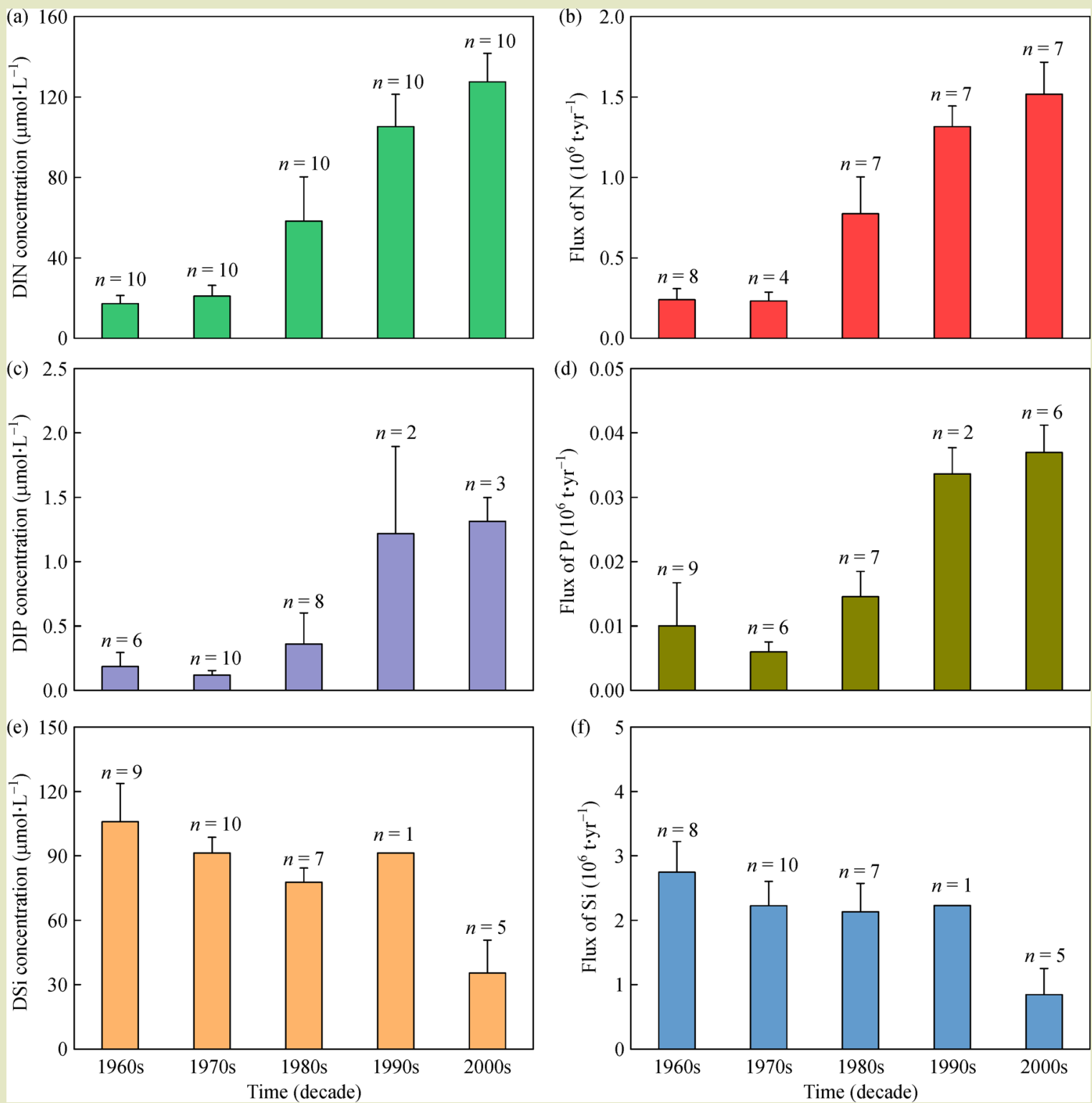

Fig. 1 Interannual variation in the concentrations and fluxes of DIN, DIP and DSi; (a) DIN concentration; (b) flux of N; (c) DIP concentration; (d) flux of P; (e) DSi concentration; (f) flux of Si. Numbers above the bars are the number of yearly data points, and the error bars indicate standard deviation. The yearly mean values of DSi, DIN, and DIP concentrations and fluxes in the river for the period between 1958 and 2010 were collected from published literature ${ }^{[2,14,17,24,29,30]}$. All data were gathered from Datong station located at the lower reaches of the river $\left(30^{\circ} 60^{\prime} \mathrm{N}\right.$, $\left.117^{\circ} 11^{\prime} \mathrm{E}\right)$. The DIN concentrations and fluxes were obtained by summing the amounts of ammonium $\left(\mathrm{NH}_{4}{ }^{+}\right)$, nitrite $\left(\mathrm{NO}_{2}{ }^{-}\right)$and nitrate $\left(\mathrm{NO}_{3}{ }^{-}\right)$ ions; DSi is mainly silicate $\left(\mathrm{SiO}_{3}{ }^{2-}\right)$; and DIP is phosphate $\left(\mathrm{PO}_{4}{ }^{3-}\right)$.

(Fig. 1 $(\mathrm{a}, \mathrm{c})$ ) is a likely explanation for the observed trends in DSi, as plankton takes up Si to form cell walls with a proposed C:Si:N: P molar ratio of 106:16:16:1 ${ }^{[32]}$. Furthermore, confinement of the river into reservoirs to control flooding and to generate power has also made a significant contribution to the decline in DSi in the river ${ }^{[33]}$. The 1990s are an outlier in the trend of decreasing
DSi over recent decades, with both concentration and flux showing slight increases relative to the 1980s (Fig. 1(e,f)). This was driven by high levels of flooding in 1998 which led to unexpected weathering of bedrock. This released high concentrations of DSi, thus increasing its flux. The absence of sufficient annual data for the 1990s and the inclusion of the outlier value 
for 1998 explain the deviation from the long-term trend for this decade $^{[34]}$.

This analysis shows large changes in the observed N:P:Si nutrient ratios in the river over time (Fig. 2). A high interannual variability in $\mathrm{N}$ and $\mathrm{P}$ nutrients was observed, with the $\mathrm{N}: \mathrm{P}$ ratio showing an increasing trend from 70 in 1964 to 193 in 1998 followed by a sharp decrease to 80-100 during 2001-2003 (Fig. 2(a)). The dominant factor affecting the DIN load in the region is most likely the use of chemical fertilizers ${ }^{[35]}$. A significant decline in the application of fertilizer- $\mathrm{N}$ after $2000^{[17]}$ is likely to be responsible for the observed decrease in $\mathrm{N} / \mathrm{P}$ ratio after 2000. This also suggests that high N/P ratios originate from large inputs of $\mathrm{N}$ compounds.

These data may indicate future trends. More attention has focused on the control of $\mathrm{P}$ in sewage treatment plants compared to $\mathrm{N}$ and the $\mathrm{N} / \mathrm{P}$ ratios in water from the cities have increased ${ }^{[36]}$. The recent trend toward the use of chemical fertilizers- $\mathrm{N}$ in the region, driven by the rapidly increasing population and increasing demand for foodstuffs ${ }^{[37]}$ will likely increase the $\mathrm{N} / \mathrm{P}$ ratio. The $\mathrm{N} / \mathrm{P}$ ratio in terrestrial ecosystems will also likely increase due to high fluxes of atmospheric $\mathrm{N}$ deposition which recent studies have shown to be an order of magnitude higher than $\mathrm{P}$ deposition fluxes ${ }^{[21]}$. Similar trends were observed in the $\mathrm{N} / \mathrm{Si}$ and $\mathrm{P} / \mathrm{Si}$ ratios, both of which increased exponentially between 1964 and $2002(p<0.001$ and $p<0.01$, respectively) (Fig. 2(b)), with annual rates of increase at 0.09 and 0.08 , respectively. A rapid increase in dam construction (162 dams with water storage capacity $>0.1 \mathrm{~km}^{3}$ ) and expanded fertilizer usage in the region ${ }^{[15,17,37]}$ suggest that further increases in the $\mathrm{N} / \mathrm{Si}$ and $\mathrm{P} / \mathrm{Si}$ ratios are likely in the future.

\subsection{Relationships between $\mathrm{N}$ inputs from major $\mathrm{N}$ sources and riverine DIN loads and fluxes}

This study focuses primarily on major $\mathrm{N}$ sources (i.e., sewage sludges, manures and atmospheric deposition over water bodies and fertilizers). We used the percentage contribution of each source to total DIN loads in the region following the study of $\mathrm{Xu}$ et al. ${ }^{[17]}$. A constant contribution from each source is assumed within each decade between the 1970s and 2000s. The DIN load (expressed in $\mu \mathrm{mol} \cdot \mathrm{L}^{-1}$ ) from each of the major sources was calculated successively by multiplying the yearly mean DIN concentration for the period from 1972 to 2000 by the source contribution fraction (Fig. 3(a)). Two years were not included in this calculation (1998, an extreme flood year, and 2006, a drought year) to avoid potentially large outliers in DIN loads. The contribution of each $\mathrm{N}$-source to the overall DIN load increased between 1970 and 2009 with average values of $13.4 \mu \mathrm{mol} \cdot \mathrm{L}^{-1}$ for fertilizer $\mathrm{N}, 19.8 \mu \mathrm{mol} \cdot \mathrm{L}^{-1}$ for sewage $\mathrm{N}$, $20.8 \mu \mathrm{mol} \cdot \mathrm{L}^{-1}$ for manure $\mathrm{N}$ and $20.3 \mu \mathrm{mol} \cdot \mathrm{L}^{-1}$ for atmospheric $\mathrm{N}$. Based on these results we suggest that DIN concentrations in the estuarine and coastal waters would also show positive responses to riverine DIN inputs from the same $\mathrm{N}$ sources. The stable long-term interannual variation in runoff at Datong Station (from 1950 to 2000) ${ }^{[14]}$ and the large spatial variation in nutrient concentrations in the Yangtze River estuarine and coastal regions ${ }^{[24]}$ made it a good location for the study of DIN. Here, we analyzed the relationships between different $\mathrm{N}$ sources and the annual riverine $\mathrm{N}$ fluxes determined at Datong Station.

The relationships between $\mathrm{N}$ sources and annual riverine $\mathrm{N}$ fluxes reflect the impact of corresponding $\mathrm{N}$ sources on DIN loads in estuarine and coastal waters. Statistically significant linear relationships were found between the riverine $\mathrm{N}$ fluxes and several variables, namely fertilizer $\mathrm{N}\left(R^{2}=0.93\right)$,
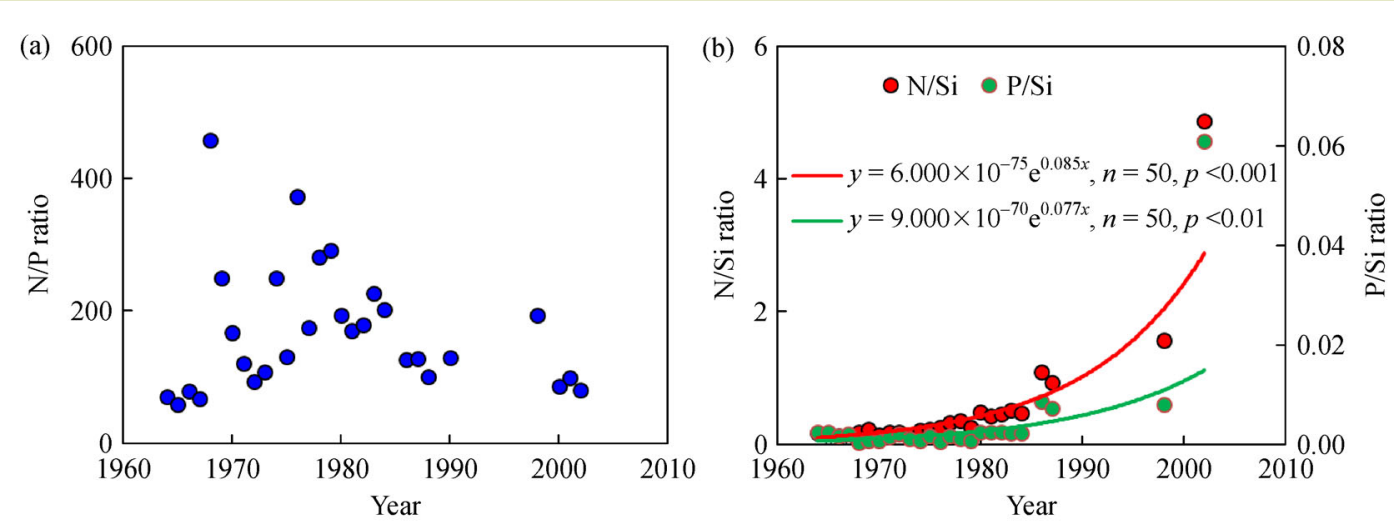

Fig. 2 Trends in ratios of (a) N/P (DIN/DIP) and (b) N/Si (DIN/DSi) and P/Si (DIP/DSi) in Yangtze River water from 1964 to 2002. 

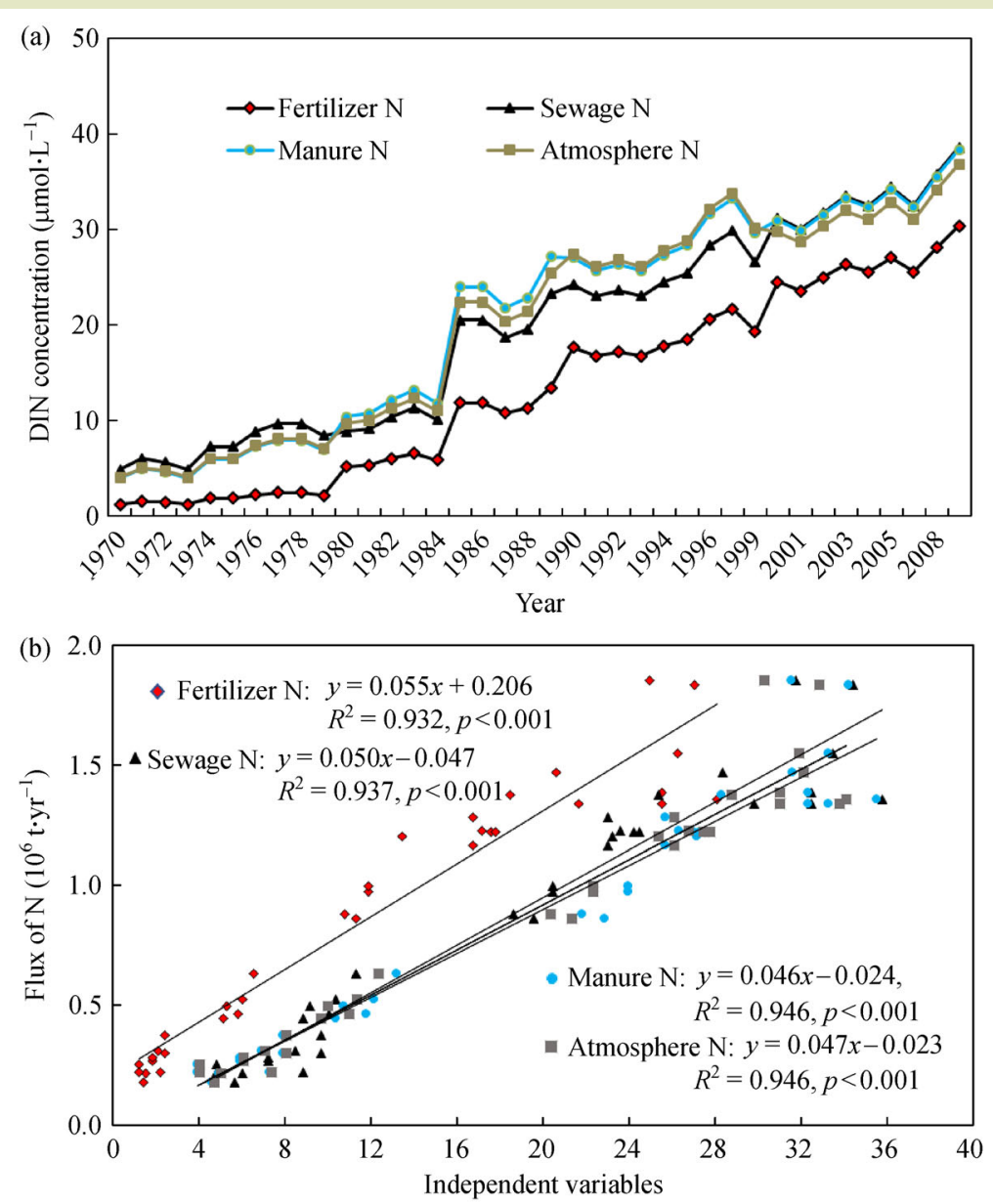

Fig. 3 (a) Temporal trends in different DIN inputs (expressed as $\mu \mathrm{mol} \cdot \mathrm{L}^{-1}$ ) to the Yangtze River for the period 1970-2009 and (b) relationships between variables (expressed as $\left.\mu \mathrm{mol} \cdot \mathrm{L}^{-1}\right)$ and fluxes of $\mathrm{N}\left(10^{6} \mathrm{t} \cdot \mathrm{yr}^{-1}\right)$. Atmospheric $\mathrm{N}$ refers to the deposition over water bodies.

atmospheric $\mathrm{N}\left(R^{2}=0.95\right)$, sewage $\mathrm{N}\left(R^{2}=0.94\right)$ and manure $\mathrm{N}$ $\left(R^{2}=0.95\right)$ (Fig. 3(b)). These relationships indicate that the inputs from these $\mathrm{N}$ sources may be used as predictors of riverine DIN flux. It should be noted that the impact of $\mathrm{N}_{2}$ fixation (the sum of symbiotic fixation by legume crops and nonsymbiotic fixation by microorganisms) was not considered in this study because only a weak relationship $\left(R^{2}=0.54\right)$ has been found between $\mathrm{N}_{2}$ fixation and riverine $\mathrm{N}$ load ${ }^{[16]}$. Based on multiple linear regression analysis, the relationship between the four main sources of nitrogen (fertilizer $\mathrm{N}, X_{1}$; sewage $\mathrm{N}, X_{2}$; manure $\mathrm{N}, X_{3}$; and atmospheric $\mathrm{N}, X_{4}$ ) and the riverine $\mathrm{N}$ fluxes was shown as $Y=0.092+0.029 X_{1}-0.014 X_{2}+0.02 X_{3}+$ $0.016 X_{4}$. These results suggest that fertilizer $\mathrm{N}$ and atmospheric $\mathrm{N}$ deposition are two most important contributors of the riverine $\mathrm{N}$ fluxes.

The YRB has experienced rapid economic development and population growth since the 1990s, leading to high emissions and tropospheric concentrations of reactive $\mathrm{N}$ compounds (e.g., $\mathrm{NH}_{3}$ and $\left.\mathrm{NO}_{2}\right)^{[38,39]}$. Significant $\mathrm{N}$ discharges into the estuary and the adjacent East China Sea have had negative ecological impacts over the past 30 years ${ }^{[40]}$. Wang et al. used a mass balance model to estimate that the contribution of DIN deposition to total $\mathrm{N}$ inputs in the region increased from $3 \%$ in 1980 to $5 \%$ in $2000^{[41]}$. Several recent studies have provided further evidence of increasing $\mathrm{N}$ pollution from anthropogenic sources. Chen et al. have also reported that atmospheric DIN deposition accounted for approximately $13 \%$ of humancontrolled $\mathrm{N}$ inputs during the period from 1980 to $2012^{[35]}$. $\mathrm{Xu}$ et al. used principal component analysis to estimate that atmospheric deposition accounted for $25 \%$ to $28 \%$ of the total riverine DIN load between 1972 and $2010^{[17]}$. About $82 \%$ of the total $\mathrm{N}$ deposition in the region exceeded the critical $\mathrm{N}$ load in the seminatural ecosystem of the basin ${ }^{[26]}$. Atmospheric $\mathrm{N}$ 
deposition may become an even more important factor in $\mathrm{N}$ cycling in the basin and the adjacent coastal ecosystem following the implementation of a regional plan (see Section 2.3).

\subsection{Impact on the estuarine ecosystem and adja- cent seas}

The expansion of red tides in the Yangtze River estuaries and nearby seas has been well documented since the 1980s (Fig. 4). The observed annual frequency of red tide outbreaks increased from 19 to 116 events between the 1970s and 2000s and increased in geographical extent from 0.4 to $42.1 \mathrm{~km}^{2}$. The main driver for this is a change in N:P:Si nutrient ratio and flux (Fig. $1(\mathrm{a}-\mathrm{f})$ and Fig. 2(a,b)). The increased presence of phytoplankton biomass in the water is indicated by the chlorophyll a (Chl a) concentration which increased by 3.9 times from 1984 $\left(2.2 \mu \mathrm{g} \cdot \mathrm{L}^{-1}\right)$ to $2002\left(8.6 \mu \mathrm{g} \cdot \mathrm{L}^{-1}\right)^{[2]}$. This indicates a strong correlation between the nutrient composition and outbreak frequency of red tides. In addition, exponential increases in the $\mathrm{N} / \mathrm{Si}$ and $\mathrm{P} / \mathrm{Si}$ ratios (Fig. 2(b)) have changed the species composition of the red tides. A higher N/Si ratio impairs the development of noxious red tide flagellates while an increased $\mathrm{P} /$ Si ratio is closely related to non-siliceous algal blooms and the eutrophication of coastal waters ${ }^{[42]}$. The analysis of algal species in the Yangtze River estuaries shows that the percentage of Skeletonema costatum (siliceous alga), the dominant species in the 1980 s, decreased from $33 \%$ to $24 \%$ by $2000-2002$, while the non-siliceous alga Prorocentrum dentatum simultaneously became a dominant species, increasing from $12.5 \%$ to $36 \%$ of the algal population ${ }^{[14]}$. Exceptionally high N/P ratios (Fig. 2(a)) may lead to the growth of phytoplankton deficient in $\mathrm{P}$ and, together with the reduced silica discharge (Fig. 1(f)), may significantly alter the structure of the planktonic food-web in the
East China Sea. The estuarine ecosystem is also greatly affected by the increased nutrient loadings which lead to oxygen depletion (hypoxia) in the deeper waters ${ }^{[43]}$. This effect has become noticeable in the mouth of the river where the minimum $\mathrm{O}_{2}$ concentration has further declined and the affected zone has increased in area $^{[44]}$.

The Yangtze River Delta has comprehensively developed and urbanized in recent decades. According to the regional plan for the Yangtze River Delta (2009-2020), this area is projected to become a central gateway to the Asia-Pacific region and a major finance, information, service and manufacturing center. This necessitates further industrialization and urbanization which will likely support further economic and population growth. Recent construction of numerous dams has reduced nutrient loads (particularly DSi) in the estuary ${ }^{[14]}$. However, increased economic activity and population will inevitably increase DIN and DIP loads in the river via further increases to industrial and municipal wastewater discharges alongside additional fertilizer usage and based on these factors it may be predicted that eutrophication of the river will likely continue.

\section{CONCLUSIONS}

The main findings of this study are as follows.

(1) Distinct interannual variations in nutrient concentrations and fluxes were found in the Yangtze River. These include sharply increasing trends in DIN and DIP and a gradually decreasing trend in DSi, mainly due to increased industrial and municipal wastewater drainage, fertilizer use and dam construction. Changes in DIN concentrations may also be related to an

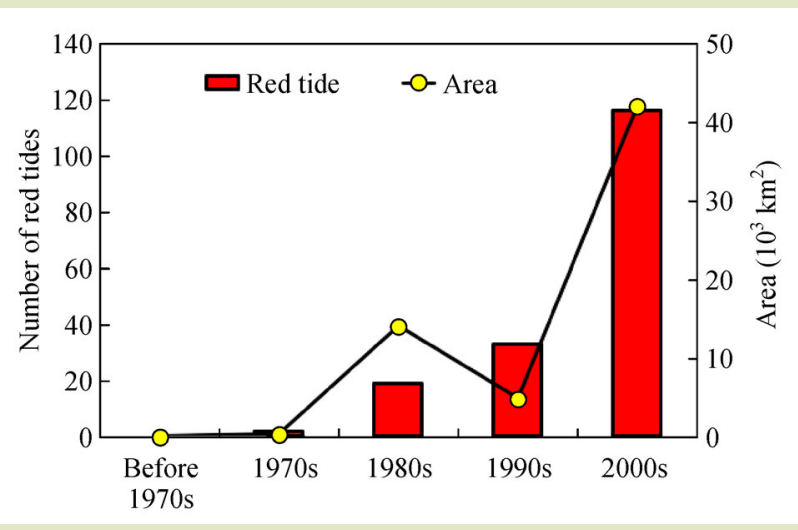

Fig. 4 Trends in number and area of red tide incidents in the Yangtze River Estuary and its adjacent seas over the last five decades. Red tide data for the period from 1933 to 2009 were obtained from published reports ${ }^{[2,3,14]}$ and from the East China Sea environmental monitoring center. 
increase in animal manures and atmospheric $\mathrm{N}$ deposition during the last decade.

(2) Red tide outbreaks in the estuary and its nearby seas increased dramatically between the 1970s and 2000s, both in number (19 events in the 1970s to 116 in the 2000s) and in geographical extent $\left(0.4-42.1 \mathrm{~km}^{2}\right)$. Given the continuing increases in anthropogenic $\mathrm{N}$ and $\mathrm{P}$ inputs into the river and continuing dam construction the occurrence of red tides is expected to further increase.

(3) Highly significant positive correlations were found between the major sources of DIN inputs and riverine $\mathrm{N}$ fluxes. These results indicate that integrated $\mathrm{N}$ inputs, especially the application of fertilizer $\mathrm{N}$ and atmospheric $\mathrm{N}$ deposition, are good predictors of riverine DIN fluxes, and that these will likely have an increasingly important role in $\mathrm{N}$ cycling in the coastal ecosystem in the future.

\section{Acknowledgements}

This work was supported by the National Natural Science Foundation of China (41705130), China Postdoctoral Science Foundation (2019T120156, 2018M641531), and Beijing Advanced Discipline. We thank Mike Wolffe of Lancaster University for his suggestions and comments.

\section{Compliance with ethics guidelines}

Yandan Fu, Jiahui Kang, Ziyue Li, Xuejun Liu, and Wen Xu declare that they have no conflicts of interest or financial conflicts to disclose. This article does not contain any studies with human or animal subjects performed by any of the authors.

\section{REFERENCES}

1. Voss M, Bange H W, Dippner J W, Middelburg J J, Montoya J P, Ward B. The marine nitrogen cycle: recent discoveries, uncertainties and the potential relevance of climate change. Philosophical Transactions of the Royal Society, 2013, 368(1621): 20130121

2. Wang B D. Cultural eutrophication in the Changjiang (Yangtze River) plume: history and perspective. Estuarine, Coastal and Shelf Science, 2006, 69(3-4): 471-477

3. Seitzinger S P, Mayorga E, Bouwman A F, Kroeze C, Beusen A H W, Billen G, Van Drecht G, Dumont E, Fekete B M, Garnier J, Harrison J A. Global river nutrient export: a scenario analysis of past and future trends. Global Biogeochemical Cycles, 2010, 24 (4): GB0A08

4. Chen C C, Gong G C, Shiah F K. Hypoxia in the East China Sea: one of the largest coastal low-oxygen areas in the world. Marine Environmental Research, 2007, 64(4): 399-408

5. Nixon S W. Coastal marine eutrophication: a definition, social causes, and future concerns. Ophelia, 2012, 41(1): 199-219

6. Diaz R J, Rosenberg R. Spreading dead zones and consequences for marine ecosystems. Science, 2008, 321(5891): 926-929

7. Anderson D M, Burkholder J M, Cochlan W P, Glibert P M, Gobler C J, Heil C A, Kudela R M, Parsons M L, Rensel J E J, Townsend D W, Trainer V L, Vargo G A. Harmful algal blooms and eutrophication: examining linkages from selected coastal regions of the United States. Harmful Algae, 2008, 8(1): 39-53

8. Heisler J, Glibert P M, Burkholder J M, Anderson D M, Cochlan W, Dennison W C, Dortch Q, Gobler C J, Heil C A, Humphries
E, Lewitus A, Magnien R, Marshall H G, Sellner K, Stockwell D A, Stoecker D K, Suddleson M. Eutrophication and harmful algal blooms: a scientific consensus. Harmful Algae, 2008, 8(1): 3-13

9. Conley D J, Paerl H W, Howarth R W, Boesch D F, Seitzinger S P, Havens K E, Lancelot C, Likens G E. Controlling eutrophication: nitrogen and phosphorus. Science, 2009, 323(5917): 1014 1015

10. Elser J J, Andersen T, Baron J S, Bergstrom A K, Jansson M, Kyle M, Nydick K R, Steger L, Hessen D O. Shifts in lake N:P stoichiometry and nutrient limitation driven by atmospheric nitrogen deposition. Science, 2009, 326(5954): 835-837

11. Tian R C, Hu F X, Martin J M. Summer nutrient fronts in the Changjiang (Yantze River) Estuary. Estuarine, Coastal and Shelf Science, 1993, 37(1): 27-41

12. Liu S M, Zhang J, Chen $\mathrm{H} T$, Wu Y, Xiong $\mathrm{H}$, Zhang Z F. Nutrients in the Changjiang and its tributaries. Biogeochemistry, 2003, 62(1): 1-18

13. Lin Z, Levy J K, Xu X, Zhao S, Hartmann J. Weather and seasonal climate prediction for flood planning in the Yangtze River Basin. Stochastic Environmental Research and Risk Assessment, 2005, 19(6): 428-437

14. Li M T, Xu K Q, Watanabe M, Chen Z Y. Long-term variations in dissolved silicate, nitrogen, and phosphorus flux from the Yangtze River into the East China Sea and impacts on estuarine ecosystem. Estuarine, Coastal and Shelf Science, 2007, 71(1-2): 3-12

15. Dai Z J, Du J Z, Zhang X L, Su N, Li J F. Variation of riverine 
material loads and environmental consequences on the Changjiang (Yangtze) Estuary in recent decades (1955-2008). Environmental Science \& Technology, 2011, 45(1): 223-227

16. Yan W J, Zhang S, Sun P, Seitzinger S P. How do nitrogen inputs to the Changjiang basin impact the Changjiang River nitrate: a temporal analysis for 1968-1997. Global Biogeochemical Cycles, 2003, 17(4): 1-8

17. Xu H, Chen Z Y, Finlayson B, Webber M, Wu X D, Li M, Chen J, Wei T Y, Barnett J, Wang M. Assessing dissolved inorganic nitrogen flux in the Yangtze River, China: sources and scenarios. Global and Planetary Change, 2013, 106: 84-89

18. Anderson D M, Glibert P M, Burkholder J M. Harmful algal blooms and eutrophication: nutrient sources, composition, and consequences. Estuarine Research Federation, 2002, 25(4): 704726

19. Paerl H W. Coastal eutrophication and harmful algal blooms: importance of atmospheric deposition and groundwater as "new" nitrogen and other nutrient sources. Limnology and Oceanography, 1997, 42(5): 1154-1165

20. Liu X J, Zhang Y, Han W X, Tang A H, Shen J B, Cui Z L, Vitousek P, Erisman J W, Goulding K, Christie P, Fangmeier A, Zhang F S. Enhanced nitrogen deposition over China. Nature, 2013, 494(7438): 459-462

21. Zhu J X, Wang Q F, He N P, Smith M D, Elser J J, Du J Q, Yuan G F, Yu G R, Yu Q. Imbalanced atmospheric nitrogen and phosphorus depositions in China: implications for nutrient limitation. Journal of Geophysical Research: Biogeosciences, 2016, 121(6): 1605-1616

22. Liu X J, Duan L, Mo J M, Du E Z, Shen J L, Lu X K, Zhang Y, Zhou X B, He C, Zhang F S. Nitrogen deposition and its ecological impact in China: an overview. Environmental Pollution, 2011, 159(10): 2251-2264

23. Yan W J, Mayorga E, Li X Y, Seitzinger S P, Bouwman A F. Increasing anthropogenic nitrogen inputs and riverine DIN exports from the Changjiang River Basin under changing human pressures. Global Biogeochemical Cycles, 2010, 24(4): GB0A06

24. Chai C, Yu Z M, Shen Z L, Song X X, Cao X H, Yao Y. Nutrient characteristics in the Yangtze River Estuary and the adjacent East China Sea before and after impoundment of the Three Gorges Dam. Science of the Total Environment, 2009, 407(16): $4687-4695$

25. Strokal M, Kroeze C, Wang M R, Bai Z H, Ma L. The MARINA model (model to assess river inputs of nutrients to seAs): model description and results for China. Science of the Total Environment, 2016, 562: 869-888

26. Xu W, Zhao Y H, Liu X J, Dore A J, Zhang L, Liu L, Cheng M. Atmospheric nitrogen deposition in the Yangtze River Basin: spatial pattern and source attribution. Environmental Pollution, 2018, 232: 546-555

27. Huang P, Zhang J B, Zhu A N, Xin X L, Zhang C Z, Ma D H. Atmospheric deposition as an important nitrogen load to a typical agroecosystem in the Huang-Huai-Hai Plain. 1. Measurement and preliminary results. Atmospheric Environ- ment, 2011, 45(20): 3400-3405

28. Huang P, Zhang J B, Ma D H, Wen Z F, Wu S J, Garland G, Pereira P E, Zhu A N, Xin X L, Zhang C Z. Atmospheric deposition as an important nitrogen load to a typical agroecosystem in the Huang-Huai-Hai Plain. 2. Seasonal and interannual variations and their implications (2008-2012). Atmospheric Environment, 2016, 129: 1-8

29. Sun C C, Shen Z Y, Xiong M, Ma F B, Li Y Y, Chen L, Liu R M. Trend of dissolved inorganic nitrogen at stations downstream from the Three Gorges Dam of Yangtze River. Environmental Pollution, 2013, 180: 13-18

30. Liu X C, Beusen A H W, Van Beek L P H, Mogollon J M, Ran X B, Bouwman A F. Exploring spatiotemporal changes of the Yangtze River (Changjiang) nitrogen and phosphorus sources, retention and export to the East China Sea and Yellow Sea. Water Research, 2018, 142: 246-255

31. Gao S, Wang Y P. Changes in material fluxes from the Changjiang River and their implications on the adjoining continental shelf ecosystem. Continental Shelf Research, 2008, 28(12): 1490-1500

32. Garnier J, Billen G, Némery J, Sebilo M. Transformations of nutrients $(\mathrm{N}, \mathrm{P}, \mathrm{Si})$ in the turbidity maximum zone of the Seine estuary and export to the sea. Estuarine, Coastal and Shelf Science, 2010, 90(3): 129-141

33. Humborg C, Ittekkot V, Cociasu A, Bodungen B. Effect of Danube River dam on Black Sea biogeochemistry and ecosystem structure. Nature, 1997, 386(6623): 385-388

34. Xu K Q, Chen Z Y, Zhao Y W, Wang Z H, Zhang J Q, Hayashi S, Murakami S, Watanabe M. Simulated sediment flux during 1998 big-flood of the Yangtze (Changjiang) River, China. Journal of Hydrology, 2005, 313(3-4): 221-233

35. Chen F, Hou L J, Liu M, Zheng Y L, Yin G Y, Lin X B, Li X F, Zong H B, Deng F Y, Gao J, Jiang X F. Net anthropogenic nitrogen inputs (NANI) into the Yangtze River Basin and the relationship with riverine nitrogen export. Journal of Geophysical Research: Biogeosciences, 2016, 121(2): 451- 465

36. Wang H J, Wang H Z. Mitigation of lake eutrophication: loosen nitrogen control and focus on phosphorus abatement. Progress in Natural Science, 2009, 19(10): 1445-1451

37. Xu X B, Tan Y, Chen S, Yang G S. Changing patterns and determinants of natural capital in the Yangtze River Delta of China 2000-2010. Science of the Total Environment, 2014, 466467: $326-337$

38. Huang J P, Zhou C H, Lee X, Bao Y X, Zhao X Y, Fung J, Richter A, Liu X, Zheng Y Q. The effects of rapid urbanization on the levels in tropospheric nitrogen dioxide and ozone over East China. Atmospheric Environment, 2013, 77: 558-567

39. Kang Y N, Liu M X, Song Y, Huang X, Yao H, Cai X H, Zhang H S, Kang L, Liu X J, Yan X Y, He H, Zhang Q, Shao M, Zhu T. High-resolution ammonia emissions inventories in China from 1980 to 2012. Atmospheric Chemistry and Physics, 2016, 16(4): 2043-2058

40. Dai Z J, Du J Z, Zhang X L, Su N, Li J F. Variation of riverine material loads and environmental consequences on the 
Changjiang (Yangtze) Estuary in recent decades (1955-2008). Environmental Science \& Technology, 2011, 45(1): 223-227

41. Wang Q X, Koshikawa H, Liu C, Otsubo K. 30-year changes in the nitrogen inputs to the Yangtze River Basin. Environmental Research Letters, 2014, 9(11): 115005

42. Officer C B, Ryther J H. The possible importance of silicon in marine eutrophication. Marine Ecology Progress Series, 1980, 3
(1): 83-91

43. Cloern J E. Our evolving conceptual model of the coastal eutrophication problem. Marine Ecology Progress Series, 2001, 210(4): 223-253

44. Li D J, Zhang J, Huang D J, Wu Y, Liang J. Oxygen depletion off the Changjiang (Yangtze River) Estuary. Science in China. Series D: Earth Sciences, 2002, 45(12): 1137-1146 